\title{
The effect of the "Transcarpathia" Free Economic Belt on the investment activities of the region and its development of foreign trade relations
}

\author{
Katalin Koval \\ Ferenc Rákóczi II Transcarpathian Hungarian Institute, Beregszász \\ kata13@kmf.uz.ua
}

Keywords: Free Economic Belt, investment, company, project

SUMMARY

The article analyses the figures of foreign investments and their territorial distribution and their change due to the impact of the "Transcarpathia" Free Economic Belt. The article studies the consequences of the liquidation of the "Transcarpathia" Free Economic Belt and the issue of restoring allowances that formerly existed on its territory.

The Free Economic Belt that was founded in 1998 and its customs and tax allowances invoked the settlement of affiliated firms of several world corporations, like the "Eurocar", the "Yadzaki", or the "Jabil". However in 2005 the government of that time repealed all allowances granted by the "Transcarpathia" Free Economic Belt, and due to this the increasing dynamics of the amount of foreign stocks which was penetrating into the economy of Transcarpathia started to decrease. Many companies halted their work which went alongside with closing-down several thousands of workplaces. The working "Transcarpathia" Free Economic Belt had a positive effect on the social and economic indices of the region, so discussions regarding its restoration have already been started between the president of Ukraine and the governor of the region.

The Transcarpathian region, which is situated in the Southwestern part of Ukraine, borders on four member states of the European Union, i.e.: Poland, Slovakia, Hungary and Romania. Its territory is $12800 \mathrm{sq} \mathrm{km}$, which makes up $2.8 \%$ of Ukraine's total territory. Its population is 1242.6 thousand, which is $2.7 \%$ of Ukraine's population. (Pop, 2009). The neighborhood of the EU (European Union), the availability of natural resources, cheap labor force and highly-qualified people offer favorable conditions to foreign investors.

There are 857 corporations of foreign ownership in Transcarpathia, in the working procedures of which one third of Transcarpathia's population takes part, which means that every fourth person works at one of these companies (Statistics Annuals, 2010). In the recent 11 years, the amount of foreign stake invested in the economy of the region was a little more than 373 million dollars (Transcarpathian Statistical Office, 2011), with which Transcarpathia is ranked 13th among the regions of the country ranked on the basis of invested foreign stake. The working capitals in Transcarpathia's economy are from 49 countries, but $65 \%$ of the inventions are provided by only five countries: USA, Japan, Germany, Hungary and Austria (Statistics Annuals, 2010). The USA makes up $15 \%$ of the total investments, with 50 million dollars, followed by Japan and its 46.6 million dollars and $13.1 \%$. Germany is the third in the list (38.5 million US dollars, and 13\% of the total investments). Hungary has $9.5 \%$ of the total investments with 33.1 million US dollars, and is followed by Austria, which is at the 5th place, with 29.6 million US dollars. The other investing countries are Poland, the Netherlands, Italy, Slovakia and Switzerland. Altogether more than $80 \%$ of the total investments come from the named ten countries, out of which $64 \%$ is possessed by the member states of the European Union (Transcarpathian Statistical Office, 2010).

Regarding branches in the field of investments, industry leads by $81.4 \%$ of the total investments (Statistical Annuals, 2010). Processing industry is also dominant (79.3\%). Out of this: food- and tobacco products-11.8\%; wood-working industry (without furniture production)-14.7\%; machine production- $24.9 \%$; textile industry- $6.4 \%$; chemical industry-3.2\%; metallurgy and metal products industry-1.3\%; mining- $0.3 \%$; and others- $15.7 \%$. In the non-production sphere $15 \%$ of the total investments is present, and has the following indices: trade- $2.9 \%$; hospitality-2.6\%; traffic and media-6.1\%; real estate-5.1\%; electricity, gas and water supplies-1.8\%. An insignificant amount is directed at agriculture and forestry $(0.7 \%)$; unfortunately, however there is a need for development, for introducing modern technologies, machines and equipment in Transcarpathia (Statistics Annuals, 2010).

As a device of agricultural and regional improvement special (free) economic belts and territories of special improvement were created in Ukraine, as well. The number of special economic belts adds up to twelve, among which districts can also be found (for example, Yavorivskiy District in Lviv region or the Ungvár and Munkács Districts in the Transcarpathian region), but the majority of them are towns. In total 80 administrative units were qualified as territories of special improvement, out of this 39 units are towns (among them each district of the Transcarpathian region), and the rest is towns (Baranhi, 2009). The development of foreign trade relations of Transcarpathia was hugely influenced by the creation of the "Transcarpathia" Free Economic Belt (TFEB), during the Kuchma regime in 1998, which includes, the town of Csap, and its surrounding along the banks of the 
River Tisza, the railway centre at Ungvár, the airport at Munkács and its surrounding, on an area of 737.3 hectares (Law of Ukraine, 2001). This belt is not a cohesive territory including several settlements, but districts divided into pieces varying in their size and offering certain allowances (Figure 1). Its formation was first and foremost induced by ,,alluring” foreign working capitals into Ukraine, with the help of which new workplaces can be created, and by the closeness of the EU. Its primary aim was to increase the export potential, to develop foreign trade relations, and to develop market infrastructure in the economically less developed regions. Products brought to the territory of the belt were not liable to taxation, or to Value Added Tax. In January 1999, a law entered into force that provided allowances to those investors, who invested a capital of more than 250 thousand USD into Transcarpathia (Imre, 2008). The other allowance, came into light in the form of a Presidential decree, and provided a 30-year long duration to those investors, who invested more than 1 million dollars into the "Transcarpathia" Free Economic Belt. According to the part of the decree dealing with the „Transcarpathia” Free Economic Belt, any type of volunteering activity can be realized in the territory of the free economic belt, apart from those forbidden by the existing laws in Ukraine (Law of Ukraine, 2001). The allowances denoted by the named two enactments resulted in the establishment of many of the affiliations of world corporations (for instance,, Skoda, Audi, Yadzaki Ukraine) (Imre, 2008).

\section{Figure 1. The location of the „Transcarpathia” Free Economic Belt on the territory of the region}

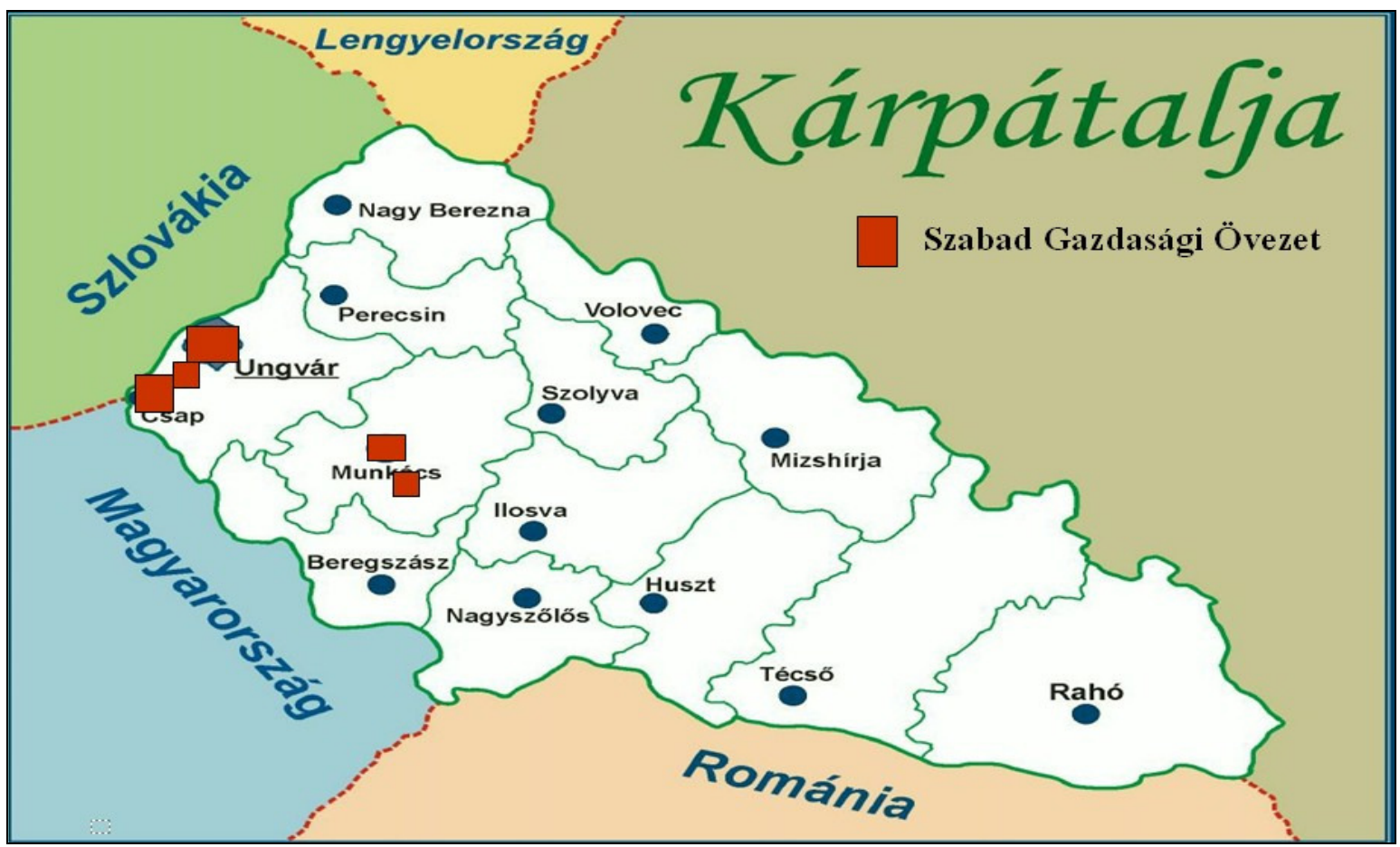

Source: Self-edited map based on a news portal of Beregszász

Allowances granted by the "Transcarpathia" Free Economic Belt and other economic belts in Ukraine, were terminated by the Timoshenko regime from April 1, 2005 (Imre, 2008). The transparency of the cooperation between the investors and Ukraine became questionable. The investors primarily objected that the abovementioned amendment in 2005, happened without any forewarning, which is unusual in Western Europe (and in the developed economic world). As a consequence of the decree, the increasing dynamics of the incoming capital significantly declined (Figure 2), which in turn negatively influenced the widening of foreign relations of the region, and its economic prosperity. Eight corporations operating in the TFEB terminated an investment of 159 million dollars. It went alongside with closing down 11,850 workplaces. Fifteen projects in the Transcarpathian Free Economic Belt remained unfinished, that would have required 163.6 USD (Lendyel and Zhulkanich, 2010). 
Figure 2. Foreign investmens which directly come into the economy of Transcarpathia

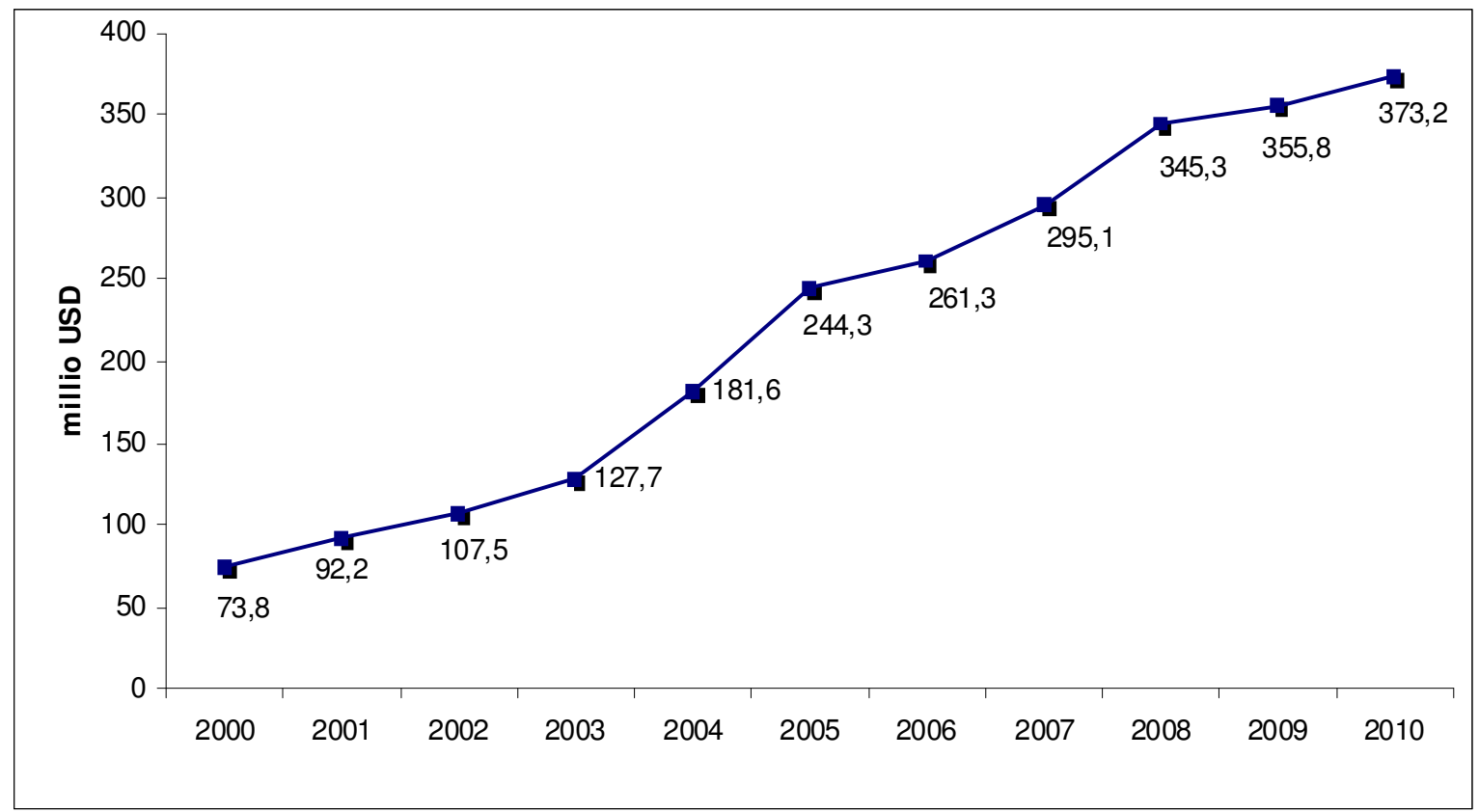

Source: On the basis of the Statistics Annuals of the region (self-edited)

With respect to the territorial distribution, in the recent one and a half decade, the most important aim of foreign investments was the Ungvár District, by possessing 19.3\% of the investments (66.4 million USD). The town of Ungvár alone received 50.5 million dollars, which mean $14.7 \%$ of the total investments (Informational bulletin, 2010). This region attracts investors mainly owing to its qualified work force and its relatively well-equipped enterprises. Similar reasons explain why foreign capitals settled down in Munkács (43.8 million USD, 12.6\% of the investments), in Beregszász (29.4 million USD, 8.5\% of the investments). Similarly significant investments happened in Rahó District (27.3 million USD), in Nagyszőlős District (21.2 million USD), and in Nagyberezna District (18.0 million USD), which can be explained by the presence of favourable natural resources. Ökörmezö District (4.8 million USD), Huszt District (2.5 million USD), and the Volóc District (1.7 million USD) obtained the slightest amount of foreign capitals (Transcarpathian Statistical Office, 2010). This fact might be interpreted as the result of the out-of-date infrastructure, lack of up-to-date equipment. In sum, it can be seen that the majority of foreign capitals is still directed at the „Transcarpathia” Free Economic Belt.

The operation of the „Transcarpathia” Free Economic Belt has the great possibility of deepening the relations between home enterprises and foreign investors and that of integrating Transcarpathia with the economy of the neighbouring countries and regions. This is why many politicians insist on renovating the TFEB, and restoring the tax and duty allowances they provided. Oleksandr Ledida, the governor of Transcarpathia raised the question of restoring the TFEB to President Viktor Yanukovich, and there were some meetings, and negotiations started. Despite of several difficulties foreign investors are still seeking possibilities Transcarpathia can provide in the field of joint ventures. Only between 2004-2010 several affiliations of world corporations in our region. Such as, Jabil, Yadzaki Ukraine, or Eurocar (Informational Bulletin, 2010).

Altogether thirty projects were realized in the „Transcarpathia” Free Economic Belt, in value of 309.5 million USD (Spassky, 2010). The most significant were as follows:

1. Zakarpatinterport Ltd.-operates and realizes the project on 10 hectares (developing traffic infrastructure at the border crossing points of Transcarpathia and European states). The main task of the project is to create an up-to-date strong financial and technical basis that will serve transporting transit products, and the whole of export-import activities.

2. Eurocar Co. Ltd.-deals with assembling various types of Skoda cars. Co-operates with the Czech Skoda and German Volkswagen car factories, so as to provide European quality cars at moderate prices in the inland market. Besides the Volkswagen Group started producing Volkswagen cars on the basis of the Eurocar. The cost of the project is 215 million USD. 
3. Autoport-Csap Co. Ltd.-started its activity in 1996 in Transcarpathia. Its main aim is to speed up the transit of consignments of goods at the Ukrainian border crossing points, to supervise the regional ecosystem, to create effective working conditions and opportunities for recreation to the participants of the transport of goods.

4. Hemikon AG PV-commercial and exhibition complex, with a production section in the "Transcarpathia" Free Economic Belt. Its main aim is to create information services of high quality, and other services (hotel, bank, transport and telecommunication). The cost of the project is 35 million USD.

5. Yadzaki Ukraine Ltd.-produces electronic equipment to the car industry in the TFEB.

6. Landkost-Invest Ltd.-serves the building procedures of a factory processing and producing meat products. The cost of the project is 13.1 million USD.

7. JUBI Ltd.-provides services solving storing and stockpiling problems. The cost of the project is 4.7 million USD.

8. Jabil Circuit Ukraine Ltd.-produces mobile phones and electronic equipments.

It is important to note, that in spite of diminishing the tax discounts in 2005, the „Transcarpathian" Free Economic Belt terminated the majority of its projects, and several enterprises ceased its activity in our region, but still, due to the remaining corporations (for example, Eurocar, Jabil, Yadzaki Ukraine) the belt remained profitable, compared to other Ukrainian free economic belts.

In the TFEB by July 1, 2011, thirteen projects will have had to be finished, which in turn had to bring an investment of 270 million USD into the economy of the region (Transcarpathian news portal, 2010). Out of this $77.8 \%$ has been implemented (5.9 million USD in the first half of 2010) (Transcarpathian Statistical Office, 2010). In the opinion of the manager of the statistical section of the regional investment department, $99.6 \%$ of the investments were directed to machine production, $0.3 \%$ to trade, and $0.1 \%$ to metal using industry. One third of the total investments is from foreign capitals, while one fourth of it belongs to Ukrainian (not Transcarpathian) enterprises. The most significant foreign partners were Japan (44 407 USD investment since the beginning of the realization of projects), Cyprus (19 548 USD), Switzerland (3 200 USD), Germany (299 000 USD), United Kingdom (100 000 USD), and Slovakia (62 000 USD) (Statistics Annuals, 2010).

Since the realization of the investment projects 4400 work places were created and remained in the areas belonging to the TFEB. In these territories the average salary were $2381 \mathrm{UAH}$ (while the Transcarpathian average salary was $1993 \mathrm{UAH}$ ), which is $28.5 \%$ more than in the adjacent period in 2009 (Transcarpathian news portal, 2010).

In order to vitalize the favorable development of the economy of Transcarpathia, the more effective use of natural and human resources, and the investment activities it would be a reasonable step to refresh the TFEB, and to restore the tax and duty allowances it provided. It is worth creating the best conditions to attract foreign investors with long-term capitals, who would create real investments to the state. Direct foreign investments play an important role in internal investments and inspire the introduction of technological advances and the more effective use of inner stocks. However, to achieve this, primarily the regional politics of the government should be changed, and the supervision of those provisions of law should be initiated, that are valid to the TFEB, with the aim of creating better conditions to the corporations working in the region. As the Ukrainian laws do not prescribe, do not give the right to the local authorities to create independent economic techniques. There is no department among the governing bodies of the region that would regulate the investment activities of the TFEB in reference to the favored economic branches of the region.

\section{REFERENCES}

Baranhi, B. [Baranyi Béla] (2009): A Kárpát - Medence régiói 11. Kárpátalja [The regions of the Carpathian basin, 11.] Dialóg Campus, Pécs - Budapest, $49 \mathrm{p}$.

Imre, G. [Imre Gabriella] (2008): Kárpátalja gazdasági fejlődésének perspektívái az Európai Unió keleti bővítésének tuikrében [Perspectives of the economic development of Transcarpathia in light of the eastern expansion of the EU]. Budapest.

Lendyel, M.- Zhulkanich, N. [Lengyel M.-Zsulkánics N.] (2010): Kárpátalja. Beruházások és építőipar [Transcarpathia. Investments and the building industry].. Fedinec, Cs.-Vehes, M. (Ed.) Kárpátalja 1919-2009, történelem, politika, kultúra [Transcarpathia 1919-2009, History, politics, and culture]. Argumentum, Budapest, 398 p.

Spassky, G. [Szpásszky Gábor] (2010): Kárpátalja szociális és gazdasági problémái az agráripari beruházásokban [The social and economic problems of Transcarpathia concerning agricultural investments]. Poliprint, Ungvár.

Закон України "Про Спеціальну Економічну Зону Закарпаття" від 22 березня 2001 року №2223-III терміном на 30 років. [Law оf Ukraine "About the Special Economic Zone in Transcarpathia" from March 22, 2001, \#2223-III, for a 30-year term].

Інформаційно-аналітична довідка щодо розвитку міжрегіонального та транскордонного співробітництва в Закарпатській області у 2009 році [Informational-analytical bulletin, about the development of interregional and transboundary cooperation in the Transcarpathian region in the year of 2009]. Ужгород, 2010.

Pop, S. [Поп Степан] (2009): Природні ресурси Закарпаття [Natural resources of Transcarpathia]. Карпати, Ужгород. 
Статистичний щорічник Закарпаття за 2009 рік. Головне управління статистики у Закарпатській області. [Statistics Annuals of Transcarpathia, 2009. Main Statistics Office in the Transcarpathian region]. Ужгород, 2010.

http://ua-reporter.com/novosti/86916, Kárpátaljai hírportál [Transcarpathian news portal].

http://www.carpathia.gov.ua/ua/156.htm, Kárpátaljai statisztikai hivatal. [Transcarpathian Statistical Office].

http://www.bereg.net.ua/varos/hun/images/terkep/ Beregszászi hírportál [Beregszász news portal]. 